\section{It is the Spirit who gives life (John 6:63): Experience and the Formulation of Theology ${ }^{*}$}

\author{
OLGA ZaPrometova ${ }^{* *}$
}

This paper was presented at the international conference "Theology of the Holy Spirit: Personal Experience and Charismatic Movements in Contemporary Churches" held in Sibiu (2014). Although the role of the charismatic experience in the history of Christianity is a well-known fact it is still of particular interest for today due to the growth of Pentecostalism and charismatic movements worldwide. By turning to Hildegard of Bingen and to Martin Luther for a better understanding of the "faith of the heart", this study aims to emphasize faith not just as a matter of understanding God but rather as experiencing the real presence of the Holy One. A particular focus is on clarifying terms and seeking the understanding of one another's positions on the issue of the Holy Spirit.

Keywords: spiritual experience, Holy Spirit, theology of the heart, Pentecostalism, dialogue

My first presentation on the comparison of teaching on the Holy Spirit in Pentecostalism and Eastern Orthodoxy was back in 2006 in the framework of the St. Andrew's $11^{\text {th }}$ annual readings on Contemporary Theological Issues. Since then, I have been working on the issue of spiritual experience in various Christian and Jewish traditions. ${ }^{1}$ We do not create God by our theology. It is because we actually encounter God that we try to understand what has happened and attempt to explain it theologically. Nowadays the value of the charismatic experience in interpreting texts gets more and more recognition, as evidenced by the recent publications of the "Religious Experience

\footnotetext{
* This paper was presented at the International Conference organized by St. Andrew's Biblical Theological Institute (Moscow, Russia), the Institute of Ecumenical Research (Sibiu, Romania), and the Development of Ecumenical Leadership in Mission Network with the support of Kerk in Actie (Utrecht, Netherlands), with the theme "Theology of the Holy Spirit", 12-15 November 2014, Sibiu, Romania.

** Olga Zaprometova, Senior Lecturer PhD for Biblical Studies and Church History at the St. Andrew's Biblical Theological Institute, Moscow (Russia). Adress: Dm. Uljanov St. 4-2-395, 119333 Moscow, Russia; e-mail: ozaprometova@gmail.com

1 Olga Zaprometova, "Bitter and Sweet Tears: Exploring the Spirituality of the Eastern Church Fathers in the Light of Post-modern «enthusiastic Christianity» in Russia" in: Rolv Olsen (ed.), Mission and Postmodernities, Oxford 2011, REGNUM EDINBURGH 2010 Series, p. 191-203; O. Zaprometova, "The Conceptualization of Religious Experience: From Solovyov to Moltmann" in: Teresa Obolevitch, Tomas Homa et al. (eds.), Russian Thought in Europe: Reception, Polemics, Development, Serii Humanitas. Studia Kulturoznawcze. Krakow 2013, p. 257-275, and others.
} 
in Early Judaism and Early Christianity" Section of the Society of Biblical Literature $(2008,2012){ }^{2}$ Faith is not just a matter of understanding God, but rather it is experiencing the real presence of the Holy One. This paper will argue that for our secularized society as it seeks for spirituality, closeness to God is infinitely more important than mere philosophical proofs of God's existence and creeds.

We should keep in mind that theology, which is usually expressed in statements, propositions and creeds differs from spirituality, which challenges contemporary scholarship by seeking a proper interdisciplinary approach to its sphere of study. ${ }^{3}$ The American Lutheran theologian Grace Adolphsen Brame points out the existence of two kinds of faith that can be defined as the "faith of the head" (belief or knowing about God) and the "faith of the heart" (trust or knowing God personally). ${ }^{4}$ Having been brought up in the Lutheran tradition, I chose for this study two representatives from Germany, who belong to two Renaissances in Europe: Hildegard of Bingen (1098-1179) and Martin Luther (1483-1546). The $12^{\text {th }}$ century Renaissance brought with it a new era in the history of Christian thought, ${ }^{5}$ and the one of the $14^{\text {th }}-16^{\text {th }}$ centuries witnessed a wide-spread revival of mystical piety; both were attempts at the reformation of Church institutions through a deeper spiritual life.

\section{Hildegard of Bingen}

Hildegard of Bingen was born into the family of a German knight who was attached to the Castle of Bickenheim (located on the bank of one of the tributaries of the Rhine that flows into it at the town of Bingen ${ }^{6}$ ). She was the youngest of ten children and admitted to having had visionary experiences even as a little girl. From the age of eight Hildegard was educated under a tutor named Jutta, an anchoress with a cell consisting of several rooms attached to a Benedictine monastery. There the girl was introduced to the Benedictine traditions of music, spinning, Biblical history, prayers, and work. She took

2 The authors of these publications are working on the development of scholarly approaches to the conceptualization of various religious experiences. See: Colleen Shantz, "Opening the Black Box: New Prospects for Analyzing Religious Experience", in C. Shantz, R. A. Werline (eds), EXPERIENTIA, Volume 2. Linking Text and Experience, Atlanta 2012, p. 1-15.

3 See: Kees Waaijman, Spiritualiteit. Vormen, Grondslagen, Methoden. Кейс Ваайман, Духовность. Формы, приниипь, подходыл. В двух томах. М.: ББИ, 2009.

4 Grace Adolphsen Brame, Faith, the Yes of the Heart. Minneapolis: Augsburg, 1999, p. 52.

5 Anselm of Canterbury, Peter Abelard, Bernard of Clairvaux, and Peter Lombard are among the most well-known. The School of Saint Victor is worthy of special study, as well as the Waldensians and the Cathars or Albigenses.

6 On the left bank of the Nahe River. 
the Benedictine habit at the age of eighteen and after the death of her tutor, Hildegard, who was then 38 years of age, was appointed to take over the leadership of the female community. Within four years Hildegard had the spiritual awakening in which she took command of her vocation and her creative life that followed. From this time on she took responsibility for sharing the visions and thoughts that had been incubating in her for years.

Her first book was created over a ten-year period ${ }^{7}$ and was called Scivias (Know the Ways). ${ }^{8}$ For Hildegard, it is the Holy Spirit who illuminates; she calls the Creator a "living" light, the Son, "flash of light", and the Spirit, "fire", emphasizing that it is the fire of the Holy Spirit which binds all things together. ${ }^{9}$ The image of Hildegard's awakening, as portrayed in her self-portrait ${ }^{10}$, pictures her as a recipient of the Pentecostal fire and makes the Holy Spirit Hildegard's and ours at the same time, as is pointed out by Matthew Fox. ${ }^{11}$ Her use of symbols ${ }^{12}$, which were prevalent for medieval Christianity, awakens us to symbolic consciousness. We have to remind ourselves that a symbol is not just an image. It represents something else by association. It is a way into the other sphere of human life which we may call "the sphere of the heart". Symbolic consciousness is holistic rather than analytic. It thinks in symbols and images rather than in words or concepts. By calling us to "know the wise ways as distinct from the foolish ways", Hildegard is carrying on the biblical wisdom tradition. ${ }^{13}$ She is referring to common symbols, inviting her followers to the same spiritual awakening, to new birth. ${ }^{14}$ Those who follow the ways of

\footnotetext{
7 A secretary was appointed for her, a young monk who took down what she dictated and put it into correct Latin grammatical form.

8 Scito vias lucis/Scito vias Domini - Know the ways of the Light/the Lord. See: https://www. questia.com/library/101095068/scivias, viewed on 25 $5^{\text {th }}$ December 2014.

9 Matthew Fox, Illuminations of Hildegard of Bingen: Text by Hildegard of Bingen with Commentary by Matthew Fox. Santa Fe 1985, p. 7, 33.

10 Ibidem, plate 2. Hildegard's Awakening: A Self-Portrait. See also: http://sfmosaic.wordpress.com/2010/11/20/hildegard-von-bingen, viewed on 29 ${ }^{\text {th }}$ December 2014.

11 Ibidem, p. 39.

12 From the Greek verb $\sigma \cup \mu \beta a \lambda \lambda \omega$, some of whose meanings are "unite, compare." As an ideal construction, a symbol keeps in itself in a hidden form all possible manifestations of an object and creates a perspective for its endless unfolding (A. Losev). See: Alexei F. Losev [А.Ф. Лосев], Symbol [Символ], in Ф.В. Константинов et al. (eds.), Философбкая Энииклопедия, Москва 1970, vol. 5, p. 10.

13 It is seen through the parallelism of the famous Torah-Psalm (Ps 119). Light is inseparable from creation and the mission of Jesus according to the Gospel of John is to bring the divine light (John 1:1-4). The conversion of Saul starts with an encounter with the divine Light as well (Acts 9:3-5).
}

14 John 3:5-8 
wisdom "will themselves become a fountain gushing from the waters of life ... For these waters - that is, the believers - are a spring that can never be exhausted or run dry. ${ }^{15}$ No one will ever have too much of them ... the waters through which we have been reborn to life have been sprinkled by the Holy Spirit". ${ }^{16}$

Although Hildegard does not use the term deification, ${ }^{17}$ it is obvious that her perception of a human's love for God expressed in prayer and mystical experience leads to the participation of a human being in the Kingdom of God.

"O Holy Spirit, you are the mighty way in which everything that is in the heavens, on earth, and under the earth, is penetrated with connectedness, penetrated with relatedness. ${ }^{18}<\ldots>$ With the breath of God that touches us, we inhale the mysterious gifts of the Holy Spirit" which arouse us from dullness and boredom. $\langle\ldots\rangle$ The God who has created me is also my own power because without God I am unable to do any good deed and because I have only through God the living spirit through which I live and am moved, through which I learn to know all my ways" ${ }^{19}$.

In celebrating humanity's deification, Hildegard acknowledges the moral responsibilities and the immense dignity that go with it. "When the salvation of good and just people is progressing favourably, justice is active through the Holy Spirit so that such people rise up in victory to God and accomplish good deeds" ${ }^{20}$ Here we have to turn to the biblical understanding of the substance of divine governance which is characterized by "righteousness and justice" as expressed in Psalms:

"The Lord is king!

Let the earth exult, the many islands rejoice!

Dense clouds are around Him,

Righteousness and justice are the base of His throne" (Ps 97:1-2).

15 John 7:37-38

16 M. Fox, Illuminations of Hildegard of Bingen, p. 8.

17 The term deification appears to be a Latinate calque of the Greek theosis rather than an accurate translation of its meaning, and this serves to obscure rather than illuminate the dialogue between Eastern and Western Christianity. Deification is the ancient theological word used to describe the process by which a Christian becomes more like God through His grace (2 Pet 1:3-4). Because of the incarnation of the Son of God, because the fullness of God has inhabited human flesh, being joined to Christ means that it is again possible to experience deification, the fulfilment of our human destiny. According to the Orthodox tradition, nourished by the Body and Blood of Christ, we are partaking in the grace of God, in His strength, in His righteousness, in His love, and are therefore enabled to serve Him and glorify Him. Thus, while remaining human, we are being deified.

18 Ibidem, p. 49.

19 Ibidem, p. 62.

20 Ibidem, p. 63. 
The righteousness of God is light and joy for those who are seeking help and protection from the wicked in the judgments of the Lord. This tradition asserts that where God is present, there is radical social transformation. Justice for Israel is rooted in the very character of the Almighty and is held up in biblical texts as the ultimate. ${ }^{21}$

However, for Hildegard, to make justice happen within and around us we need self-discipline. She defines self-discipline as an accumulation of strengths and a preservation of powers of justice, clarifying that it "is justice which, when sprinkled still more by the Holy Spirit, ought to germinate good works through holiness," and emphasizes that it renders us "moist and open to being sprinkled still more by the Holy Spirit". According to Hildegard, when we ignore this lesson we succumb to dryness and "lack an infusion of heavenly dew", our souls "waste away" and, as a result, we become instruments of injustice. ${ }^{22}$ Much of the difficulty in understanding the texts analysed arises from the difficulty in recognizing what is metaphorical (and what is not) and in perceiving the meaning of the metaphor. In Scivias metaphors come in many shapes and sizes, embedded in biblical history and medieval symbolic consciousness. Sometimes several metaphors are used to describe the richness of a concept's meaning and thus a new theological interpretation is born:

"The power of human virtue is fulfilled in the fire of the Holy Spirit and the moisture of humility within the vessel of the Holy Spirit, where Wisdom has made her abode. $<\ldots>$ It is also the presence of God: the Shekinah where wisdom has set up her tent". ${ }^{23}$

Thus the Holy Spirit becomes the vessel and the instrument of divine Wisdom which transforms the heart of a human being, bringing about repentance and creating out of it a temple for the Almighty.

"It is through water that the Holy Spirit overcomes all injustice, bringing to fulfilment all the Spirit's gifts. $<\ldots>$ With these gifts humankind might thrive in the moisture of justice and stream of spiritual things in the current of truth". ${ }^{24}$

The breath of the Holy Spirit is compared with rain waters that lead a person, like mild air, to the maturity of good fruits or good works. ${ }^{25}$ And even more:

21 Walter Brueggemann, one of the most influential Old Testament scholars and theologians of today, points to two forms of justice, which he identifies as retributive and distributive, represented in the Old Testament. See: Walter Brueggemann, Theology of the Old Testament, Minneapolis 1997, p.733-742.

22 M. Fox, Illuminations of Hildegard of Bingen, p. 63.

23 Ibidem, p. 69.

24 Ibidem, p. 93.

25 Ibidem, p. 119. 
the Holy Spirit kindles the hearts of humankind and plays them like tympanum or lyre, "gathering volume in the temple of the soul." ${ }^{26}$ Hildegard concludes her book and her meditations with Psalm 150, the vision of the communion of saints making music for the cosmos. Her personal experiences and her gifts, which were many and expanded the framework of the subject chosen for study, resulted in theological thinking. According to Hildegard, we humans are to become musical instruments which the Holy Spirit plays: Let every spirit praise the Lord!'Through careful exegesis of the psalm, she endorsed each of the expressions of music that it invokes - including that of the "dance of exultation". ${ }^{27}$

In 1983 the international society of Hildegard von Bingen Studies was established whose purpose is to promote study, criticism, research, and exchange of ideas related to all aspects of her work ${ }^{28}$. Recognized by contemporary scholars as a visionary, poet, composer ${ }^{29}$, naturalist, healer, founder of convents and theologian, Hildegard was officially declared a saint of the Roman Catholic Church by Pope Benedict XVI and named a Doctor of the Church $^{30}$ in 2012.

\section{Martin Luther}

Turning to Martin Luther we always have to keep in mind that his theology is bound up with his life (as in the case with Hildegard), so that one cannot understand one apart from the other. Entering the Augustinian monastery to prepare for death - to make himself agreeable in the sight of God, Luther, like Hildegard, gave himself to his vocation completely (at the age of 21). Later in Wittenberg his superior Johann von Staupitz introduced Luther to Scripture studies and to the German mystics as an alternative way of salvation. ${ }^{31}$ The solution for the problem of sin and grace or justice and love was found by the future Reformer when he was studying the epistle to the Romans. ${ }^{32}$ Through

\footnotetext{
26 Ibidem, p. 160.

27 Ibidem, p. 162.
}

28 Of special interest for future study are the five songs to the Holy Spirit. See: http://www. hildegard-society.org/2014/11/spiritus-sanctus-vivificans-antiphon.html, viewed on $22^{\text {nd }}$ December 2014.

29 Hildegard of Bingen, "Voice of the Living Light", http://www.youtube.com/watch?v=Dehwp_dRIYQ, viewed on $22^{\text {nd }}$ December 2014.

30 She was the fourth woman to be so honoured, after Teresa of Avila, Catherine of Siena and Thérèse of Lisieux.

31 Justo L. Gonzalez, A History of Christian Thought. From the Protestant Reformation to the Twentieth Century, Vol. III, Nashville 1987, p. 30-47.

32 Hans Lilje, Martin Luther 1483/1983, Bonn, p. 53-55; Lewis W. Spitz, The Renaissance and Reformation Movements. Vol. II. The Reformation. Льюис В. Спиц, История Реформации, т. 2, Минск, 2002, с. 46-49. 
that spiritual experience, which is well known, he realized that justice and love are interconnected in a mysterious way. Still, the starting point of theology for Luther was neither reason nor experience; it was God's own action through the Holy Spirit and the Scriptures. For the great Reformer faith is not just a matter of understanding God, but of experiencing the real presence of the holy/the Holy One. It is not just a matter of saying what we believe, but of living what we believe, by practising it. Faith is what empowers us to dare to share what matters most with others who are searching for meaning and purpose in their lives. Faith that is the experience of God's presence, which trusts in God because it is certain it can depend upon God, is what Luther called "the yes of the heart". ${ }^{33}$ This statement was spoken in a sermon Luther delivered six years before he died ${ }^{34}$. Within a few decades after Luther died, Lutheran theology moved in a direction that ignored or slighted much of Luther's spirituality, his personal, experiential relationship with God. This move, according to Grace Brame, has made a critical difference in how we perceive him now. ${ }^{35}$ In her monograph, entitled "Faith, the yes of the heart" this American Lutheran scholar emphasizes that there are two kinds of faith that can be defined as the "faith of the head" (belief = knowing about God) and the "faith of the heart' (trust = knowing God personally). ${ }^{36}$

"When I believe from the heart that Christ did this for me, I receive also the same Holy Spirit that makes me entirely new. ... Then ... I do everything he desires of me, as Paul says in Philippians 4:13: 'I can do all things through Christ [who] strengthens me." ${ }^{37}$

The emphasis on Luther's "yes of the heart" points to a security that comes only by one means: "the Holy Spirit is present and writes it in the heart." ${ }^{38}$ The New Testament has numerous references to the coming of the Holy Spirit to us, among us, and into us; of Christ's life as our life, and of God within. ${ }^{39}$ In The Freedom of a Christian, Luther writes: "God teaches us inwardly through the living instruction of his Spirit." ${ }^{40}$ And even more:

\footnotetext{
33 "Fides ist ein herzlich jawort, das drauff stirbt" "Faith is the yes of the heart, a conviction on which one stakes one's life"- Martin Luther, "Sermon for the Sunday after the Feast of the Circumcision, January 4, 1540”, Weimar Edition (WA), vol.49, p.9. See: G. Brame, Faith, the Yes of the Heart. Minneapolis/Augsburg 1999, p. 171.

34 Ibidem, p. 17.

35 Ibidem, p. 13.

36 Ibidem, p. 52.

37 Ibidem, p. 29.

38 Ibidem, p. 43.

39 Matt 10:20; John 3:8, 34; 6:63; 14:17; 15:26; 16:13; Acts 2:4 and many others.

$40 \quad$ Ibidem, p. 59.
} 
"No one can understand God or his Word if he has not been enlightened by the Holy Spirit. The action of the Holy Spirit has to be experienced, sustained, and felt, and it is by undergoing these experiences that one passes through the school of the Holy Spirit. If one has not gone through it, words remain no more than words. We can know God only through the work that he does in us". ${ }^{41}$

Brame underlines that we are not saved by our theology, nor are we saved by our spirituality. We are saved (healed, made whole, and freed from bitterness, fear, and arrogance) by the grace of the Holy Spirit. ${ }^{42}$ In his Small Catechism, a book written for fathers to use in teaching their families, Luther gave his explanation to the Third Article of the Apostles' Creed in the most memorable words:

"I cannot, by my own understanding or effort, believe in Jesus Christ my Lord, or come to Him. But the Holy Spirit has called me through the Gospel, enlightened me with his gifts, and sanctified and kept me in true faith. In the same way he calls, gathers, enlightens, and sanctifies ... the whole Christian Church on earth". ${ }^{43}$ (emphasis added)

Luther, insisting that Christ can be present in a believer, did not hesitate to use the concept of theosis/deification or divinization ${ }^{44}$ (German - Vergöttlichung) in the same sense as used by the early Church, as I showed earlier. ${ }^{45}$ The development of this concept owes its most decisive advancement to Paul. ${ }^{46}$ For

41 Martin Luther, WA, 7:546; Quoted according to: G. Brame, Faith, the Yes, p. 59.

42 G. Brame, Faith, the Yes, p. 64.

43 Ich glaube, daß ich nicht aus eigener Vernunft noch Kraft an Jesus Christus, meinen Herrn, glauben oder zu ihm kommen kann; sondern der Heilige Geist hat mich durch das Evangelium berufen, mit seinen Gaben erleuchtet, im rechten Glauben geheiligt und erhalten; gleichwie er die ganze Christenheit auf Erden beruft, sammelt, erleuchtet, heiliget und bei Jesus Christus erhält im rechten, einigen Glauben; Evangelisches Kirchen-Gesangbuch. Berlin, 1974, p. 49.

44 Theosis includes two complementary stages of deification: the process towards deification and the state of deification. Gregory the Theologian affirms that the first "stage of theosis" takes place in our current life, and the second one will be accomplished in the age to come; now we have only a foretaste of theosis, but there is the eschatological theosis that is waiting for us at the "fulfilment of times", the one we will be able to enjoy fully. The way leading to deification is a human being's love for God, as expressed in prayer and mystical experience as well as in the fulfilment of the New Testament commandments. Although God still remains unknowable, inexpressible, unreachable, and invisible, prayer is primarily a meeting with the living God. O. Zaprometova, "Bitter and Sweet Tears", p. 191-203.

45 O. Zaprometova, "Experiencing the Holy Spirit: A Pentecostal Reading of the Early Church Fathers: Part 2. Isaac of Nineveh and Simeon the New Theologian" in: JEPTA 30 (1/2010), p.1-19.

46 To share the "newness of life" (Rom 6:4) or to become a "new creation" (2 Cor 5:17, Eph 2:4-10) a person must be conformed to the image of Christ (Rom 8:29), etc. See: Jules Gross, The Divinization of the Christian according to the Greek Fathers. Anaheim 2002, p. 82-83. 
Luther, faith was partaking in the existence of God that is possible due to the Holy Spirit and it is through the Holy Spirit's outpouring of the love of God upon a person, that that person becomes a means of transmission of divine grace. This process, whereby through the acquisition of the Holy Spirit Christians become participants in the Kingdom of God, begins here in time and space, but it is not static or complete; rather it is an open-ended progression uninterrupted through all eternity.

Thus, one may note that Hildegard of Bingen and Martin Luther had a lot in common: they were faithful to their vocation, were well-educated (each in a different way, however, a best possible for their time and milieu) and had pastoral responsibilities. Both wrote about the Spirit's illumination (Hildegard) and enlightenment (Luther), rebirth to life (Hildegard) and becoming participants of the Kingdom of God (Luther), giving wisdom (Hildegard) and the school of the Spirit (Luther). Hildegard's symbolic consciousness describes the Father as living light, the Son as a flash of light, and the Spirit as fire, but it is the Spirit that binds all things together in love. The representatives of the German Renaissances chosen for this study were recipients of the gifts of the Spirit, which is obvious also in their music and hymns, and produced abundant fruit(s) of the Spirit through good deeds (human virtues and missionary zeal).

It is impossible not to mention here John Wesley and his idea of sanctification before moving on to Pentecostalism. Faith filled with love, produced in a human being by God's grace, is at the core of his theology, with the concept of sanctification at its very heart: "God whispers to us by his Spirit directly witnessing within us, and what our own hearts say to us as a consequence." ${ }^{47}$

According to Wesley, sanctification is the work of God's grace, not an expression of human ability:

"It is the work of the Spirit by which God by grace seeks completely to mend the broken human condition, to bring our stunned lives to fulfilment, not partially, but wholly in a victory over all sin in this life, through a genuine renewal of all the redeemed powers of the believer". ${ }^{48}$

Like Patristic tradition, like Hildegard of Bingen and Martin Luther, Wesley, who is sometimes said to be the grandfather of Pentecostalism, emphasized that likeness to Christ is achieved gradually by a process of conscious response to the calling of God (through the Holy Spirit) and acceptance of the grace offered by Him.

\footnotetext{
47 Quoted according to: Thomas C. Oden, John Wesley's Scriptural Christianity: A Plain Exposition of His Teaching on Christian Doctrine, Grand Rapids 1994, p. 230. The Wesleyan societies were intensive dialogical processes, interacting, interpersonally encountering, exceedingly self-disclosing and personally open.
}

48 Ibidem, p. 327. 


\section{Pentecostalism}

It is the Spirit who gives life (John 6:63) ... this statement is still true today. I joined the underground Pentecostal church at the age of twenty-three, having personal spiritual experiences even earlier. The Pentecostal Movement that places a great deal of emphasis on religious experience is now over a century old and can be thought of as having expanded in three waves: Pentecostals (or Classical Pentecostals), Charismatics/Neo-Pentecostals ${ }^{49}$ and Neo-Charismatics or Independent Charismatics. There was no single founder of the movement and different scholars trace its origins to one place or to a series of spontaneous, explosive effects setting it off globally. ${ }^{50}$ The Pentecostal message, defined by Steven Land as the integration of Holiness and Power, came with the experience of the Spirit (Acts 2), with the spiritual encounter with the Divine. ${ }^{51}$

The central emphasis of Pentecostalism is not religious truths as objects of abstract belief (or the "faith of the head" that was mentioned earlier), but is rather personal, first-hand knowledge of God (the "faith of the heart"). Its epistemology is described by Pentecostal scholars with reference to the Hebrew term yada (to know), which is generally "treated as knowledge which comes through experience." 52 Theologically, European Pentecostal denominations are defined by Jean-Daniel Plüss, a contemporary Swiss scholar, as "independent, sometimes radical, perhaps on occasion obstinate, grandchildren of the Reformation" $:{ }^{53}$ however, this is not the case worldwide. ${ }^{54}$ Due to different expressions of the Spirit experience in each cultural context, it is possible to speak about "indigenisation" of the Pentecostal movement globally. One of the best approaches to Pentecostal theology in my opinion was

49 Christians affiliated with non-Pentecostal denominations, such as Anglican, Non-conformist, Catholic or Orthodox, who receive the Charismatic experiences or those renewed in the Spirit (1967-84).

50 See: Cecil M. Robeck, Jr., The Azusa Street Mission and Revival: The Birth of the Global Pentecostal Movement, Nashville 2006; Vinson Synan (gen. ed.), Spirit-Empowered Christianity in the 21st Century, Lake Mary 2011; William K. Kay, Anne D. Dyer (eds.), European Pentecostalism, Leiden 2011; Harold D. Hunter, Neil Ormerod (eds.), The Many Faces of Global Pentecostalism, Cleveland 2013; and others.

51 Steven Land, Pentecostal Spirituality: A Passion for the Kingdom, Sheffield 1993, p.15-57.

52 Cheryl Bridges Johns, Jackie D. Johns, "Yielding to the Spirit: A Pentecostal Approach to Group Bible Study" in: Journal of Pentecostal Theology 1 (1992), p.109-34.

53 Jean-Daniel Plüss, "Pentecostal Theology and Protestant Europe" in: William K. Kay, Anne D. Dyer (eds.), European Pentecostalism, Leiden 2011, p. 294-311.

54 Harold D. Hunter, "Introduction: Global Pentecostals are not «Protestants" and are not "Western»" in: The Many Faces of Global Pentecostalism, p. 1-5. 
proposed by Paul N. van der Laan. This Dutch scholar introduces Pentecostalism as a paradigm shift in theological thinking. By suggesting the use of Pentecostal quadrilateral methodology (experiential, scriptural, prophetic and intercultural) he proposed a new definition of Pentecostal theology as a "Theology of the Heart". 55

It is also important to mention that there is a lot of criticism of the Full Gospel meaning. ${ }^{56}$ Some contemporary scholars go so far as to question the search of Pentecostals for God. Traditional churches often treat the Pentecostal/Charismatic experience with suspicion and emphasize the importance of the fruit of the Spirit as a universal test of the gift of the Spirit. According to Norman Gulley, an Adventist theologian, the danger of Pentecostalism is that in this movement "Christians find themselves caught up in an experience opposed by and beyond the safety of God's Word." 57 The Russian Orthodox scholar, Metropolitan Hilarion Alfeyev, when pointing to the special role of mystical experience in Christian life, does not wish even to discuss the mystical experience of groups that exist outside the official Church. ${ }^{58}$ We have to recognize the fact that all over the world there is still much tension and distrust between established churches and their emerging counterparts that are often of Pentecostal/charismatic orientation. This is also true for Russia as evidenced by Oksana Kuropatkina. ${ }^{59}$

At the end of the $20^{\text {th }}$ century a few Pentecostal scholars entered the arena of ecumenical and intercultural dialogue. Since its early days theology was born and developed in dialogue. ${ }^{60}$ It started in the late antiquity and the disputes about the concept of Law/Torah that was at the centre of the

55 Paul N. van der Laan, "Catching a Butterfly - The Identity of Pentecostal Theology" in: JEPTA 2 (2009), p. 33-48.

56 For Pentecostals the Gospel message always includes the baptism of the Holy Spirit, pointing out that without it there is no fullness in preaching the good news.

57 Norman R. Gulley, Christ is coming! A Christ-centered approach to Last-Day Events, Hagerstown 1998, p. 132-158.

58 He calls the spiritual experiences of such examples as Montanists "heretical" mysticism, and claims that the main criterion for differentiating 'true' from 'heretical' mysticism is whether or not it conforms to the tradition of the Church. Hilarion Alfeyev, St. Simeon the New Theologian and the Orthodox Tradition. Moscow 1998, p. 444.

59 See: http://www.sova-center.ru/religion/publications/2006/12/d9729; http://www.dissercat.com/content/religioznaya-i-sotsiokulturnaya-samoidentifikatsiya-novykh-pyatidesyatnikov-v-rossii, viewed on 29 ${ }^{\text {th }}$ December 2014.

60 It might be traced to the birth of the Church and the formulation of its foundational doctrines as the content of saving knowledge, derived from the word of God. The Apostolic Council in Jerusalem (c. A.D. 49), which was of tremendous importance for the government of the Church, might be given as one of the examples (Acts 15: 6-29). 
discussion within both Judaism and Christianity. The foundational symbol of Jewish culture, the Torah, strongly rejected by surrounding nations, was emerging with the passage of time as a messenger from earlier cultural eras to remind the Church of its ancient foundations in Jewish culture. The spiritual experiences of the apostle Peter in Caesarea (Acts 10:9-48) challenged his 'theological' thinking and moved him to overcome his traditional understanding of the Torah. It was the personal testimonies of Peter, Barnabas and Paul (Acts 15: 7-12), which encouraged the members of the council in Jerusalem to go beyond the boundaries of their own tradition regarding the disputed issue. The new theological thinking was born as a result, and its foundation was rooted in the new interpretation of the Torah guided by the Spirit experience: For it seemed good to the Holy Spirit, and to us ... (Acts 15:28a). This demonstrates for us the importance of the guidance of the Holy Spirit for the Church in its formational period and it has to be the same nowadays.

Within the framework of ecumenical encounters various theologies are discussed, argued and rethought by the participants, who have to accept the diversity in Christendom. It is of great importance for Pentecostals to learn from the traditional churches; however, let us not forget that Christianity, which flourished in Asia Minor and Northern Africa in the first century, was dislodged from there to the West and North in the second millennium. At the present time, we are witnessing the reverse movement - about $63 \%$ of global Christians are now found in the southern continents. According to Wonsuk $\mathrm{Ma}, 50 \%$ of Christians in Asia are Pentecostal and Charismatic in their orientation, compared to 33\% in Africa and 28\% in Latin America. ${ }^{61}$ Still, in our global context it is becoming more obvious that no Christian tradition will be sufficient in itself. The challenge of identity in our changing world demands a development of new approaches to theological thinking. For emerging Pentecostal scholarship the critical analysis of its diverse contextualized histories and theologies has to be undertaken in dialogue with theologians and scholars of other traditions. Exploring the ways of formulating theology based on the Spirit experience, which is the common emphasis of Pentecostal and Charismatic communities throughout Church History, could help these movements and traditional churches to find a way to mutual understanding and future co-operation in overcoming the crisis our secularized society is going through.

I believe the research of the Russian Orthodox scholar Mikhail Aksenov-Meerson is among the best available in contemporary Russia to show the recent turn of theological thought from its ontological and dogmatic way of

${ }^{61}$ Ma Wonsuk, "A Global Shift of World Christianity and Pentecostalism" in: The Many Faces, p. 62-70. 
perceiving religious experience (or the "faith of the head") to a personalistic one (the "faith of the heart"), one that follows the trajectory of contemporary philosophy and its interest in anthropology. ${ }^{62}$ In this version of the development of the Trinitarian paradigm, the Russian-American scholar has managed to bring together the traditions of the Church Fathers, German classical philosophy and the personalism of Russian religious thought of the Silver Age. Through his research Aksenov-Meerson introduces a new concept, which he defines as the paradigm of love that is shared by both Western and Eastern theology. However, it is not cultural traditions or philosophies, but human beings that meet and share, ignore or enrich one another, clash and fight. Pentecostals and Charismatics are no longer in their infancy, the movements are getting older and have a lot to learn from their elder sisters and brothers - representatives of the historic churches. By turning to Church History, to the experiences of Hildegard of Bingen and Martin Luther, recorded in their works, Pentecostals learn to analyse their own recent history. In its turn Pentecostalism may share its own "theology of love" and its emphasis of the centrality of Spirit-experience which is infinitely more important to our secularized world than creeds.

The growing interest and the recent turn of at least some part of Russian contemporary society to biblical sources and Christian values might be shown through the recent publication of the collection of articles entitled The Philosophy of the Law of the Pentateuch (2012). ${ }^{63}$ The space limitations of an article do not allow an analysis of this book in detail, but it is still important to note that it exalts covenant relationships and the concept of Torah, which are inseparable from experiencing the presence of the Almighty. It is thus not a surprise that the same tendency to go to our common roots in Western European Christian thinking by turning to the issue of the righteousness and justice of God (as was shown above using the illuminations of Hildegard of Bingen) is evidenced in the works of Jürgen Moltmann.

One of the most influential theologians of the $20^{\text {th }}$ century, he demonstrates that the experience of the Spirit is equal to the experience of fellowship (2 Cor 13:13), which means "opening for one another, giving one another a

62 Mikhail Aksenov-Meerson (b. 1942), whose doctoral thesis "The Love Paradigm and the Retrieval of Western Medieval Love Mysticism in Modern Russian Trinitarian Thought" was defended in 1996 in New York (Fordham University, the Jesuit University of New York), started his research in the area of Russian religious philosophy while still in Russia back in the mid-1960s. Mikhail Aksenov-Meerson, Михаил Аксенов-Меерсон, Созерианием Троицы Святой... Парадигма Любви в русской билософии троичности, Киев 2007.

63 Филособия права Пятикнижия. Collection of articles edited by A. Gusejnov, E. Rashkovsky, Сборник статей под ред. А.А. Гусейнова и Е.Б. Рашковского. Москва, 2012. $576 \mathrm{c}$. 
share in ourselves." ${ }^{64}$ Moltmann challenges contemporary Christianity to "look for a third way, so as to discover God's love in the love between human beings, and the love between human beings in God's love" comparing Patristic and medieval traditions with modern European humanism. ${ }^{65}$ According to Moltmann, after the hierarchical church of God the Father, Christianity came to know the brotherly church of God the Son, and today we are experiencing the charismatic church of God the Spirit. ${ }^{66}$ Still the future of Christianity is in a trinitarian experience of God which is inseparable from the idea of perichoresis ${ }^{67}$, derived from Patristic theology and incorporated into contemporary theological thinking. Mel Roebeck, one of the ecumenical pioneers among Pentecostals, in reviewing his participation in the Ecumenical Movement over the past thirty years, confessed that this was a very difficult task. In his presentation at the recent joint conference of the European Pentecostal Charismatic Research Association with the European Pentecostal Theological Association and the Chemin NeufCommunity ${ }^{68}$ "Pentecostalism: an Ecumenical Challenge" (St. Niklausen, Switzerland, 26-29 June 2014) he referred to Lesslie Newbigin's arguments for the importance of Catholic, Protestant, and Pentecostal cooperation in such a way as to be one, "a koinonia, sharing in the Holy Spirit". ${ }^{69}$

\section{Conclusion}

Not everyone will agree with viewing Hildegard of Bingen and Martin Luther as proto-Pentecostals, but great value is to be found in their attempts at formulating theology based on their personal spiritual experiences. The more Pentecostal and Charismatic theologians are introduced to the writings of the Church Fathers and Mothers, among whom we may include Martin Luther and Hildegard of Bingen, the more their language, and its symbolic

64 Jürgen Moltmann, The Spirit of Life: A Universal Affirmation, trans. by M. Kohl, Minneapolis 1994, p. 218.

65 Ibidem, p. 248.

${ }^{66}$ J. Moltmann, Sun of Righteousness, Arise! God's Future for Humanity and the Earth, London 2010, p. 25-27.

67 Perichoresis (Greek) - "penetration". This is a term used in the theology of the Trinity to indicate the intimate union, mutual indwelling, or mutual interpenetration of the three members of the Trinity with each other. See: Donald K. McKim, Westminster Dictionary of Theological Terms, Kentucky 1996, p. 207.

68 A Roman Catholic community with an ecumenical vocation, which grew up out of a prayer group in Lyon, France, in 1973.

69 See: February 4, 2013: Dr. Mel Robeck, "Creative Imagination and Ecumenism: Implications of Changing Demographics" at Catholic University of America, Caldwell Hall. - See more at: http://washtheocon.org/for-the-public/figel-address/\#sthash.fVmbxTao.dpuf, viewed on $28^{\text {th }}$ December 2014. 
means of theological expression is revealed to our contemporaries, and helps them in analyzing their own spirituality.

We may wish for better understanding of the challenges that spiritual movements such as Pentecostalism pose to the traditional churches. Contemporary theology seeking for new paradigms is trying to find a possibility to bring together the hierarchical paradigm (one God - one bishop - one community), the Christocentric paradigm (the unity of the church is established through the brotherhood of Christ), and the Charismatic paradigm (experiencing fellowship with God/Holy Spirit is binding people together), as defined by Moltmann. Both Moltmann and Aksenov-Meerson, as well as many others, in referring to the concept of perichoresis, stir up our symbolic consciousness by turning to Andrei Rublev's famous icon painting. ${ }^{70}$ The image of the three angels who visited Abraham at the Oak of Mamre (Gen 18) is full of symbolism and invites us to its interpretation. Many aspects of the theological understanding of the Trinity such as love and community, which became central for $20^{\text {th }}$ century theology, were foreseen by Vladimir Solovyov (1853-1900). ${ }^{71}$ The love paradigm offered by Aksenov-Meerson and his seminal and provocative idea of all-unity may be traced through Russian religious philosophical thought, its "new religious consciousness" and its symbolism. Hildegard of Bingen and Martin Luther, deeply rooted in the biblical wisdom tradition and the cultural context of their time, confirmed the necessity of the Spirit's illumination/enlightenment and schooling, as was shown in this paper.

To seek to formulate new approaches to the urgent theological issues of today we need to get to know each other, to build bridges, to meet each other, to start constructive dialogue, to communicate with each other on different levels, pursuing the fulfilment of His commandment to love one another and His prayer for our unity (John 17:20-23). Christians of different traditions are to dare to step out beyond the borders of their own tradition, like Peter, Barnabas and Paul, and many who followed in their footsteps. We have to admit that we are to venture outside the box of our traditional prejudices and to get to know those who differ from our traditional historic churches or Pentecostalism. In view of the ecumenical challenge of today, let us seek the guidance of the Holy Spirit to clarify our traditional suspicion of each other's views, to reconcile the members of the Church and to be more involved in building a proper relationship with the Almighty and with each other for the sake of the coming Kingdom of God.

70 See: http://www.wellsprings.org.uk/rublevs_icon/rublev.htm, viewed on $29^{\text {th }}$ December 2014 .

71 O. Zaprometova, “The Conceptualization”, p. 257-275. 